\title{
Pantun Melayu: Analisis Ayat Majmuk Pancangan Bahasa Melayu
}

\author{
${ }^{1}$ AB. RAZAK AB. KARIM \\ ${ }^{2}$ NURUL AIN BINTI ALIZUDDIN \\ Jabatan Bahasa Melayu, Akademi Pengajian Melayu, Universiti Malaya, 50603 Kuala Lumpur, Malaysia. \\ 'abrazak@um.edu.my,2nurulain@um.edu.my
}

\begin{abstract}
Abstrak Makalah ini berfokus pada ayat majmuk pancangan bahasa Melayu yang digunakan dalam pantun Melayu. Kajian ini berlandaskan Teori Transformasi Generatif Standard yang diaplikasikan dalam Tatabahasa Dewan (2010). Dalam menerbitkan ayat majmuk pancangan, berlaku prosesproses transformasi seperti pengguguran, peluasan dan penyusunan semula. Analisis ayat dilakukan berdasarkan struktur dalaman dan permukaan dengan rajah pohon dan keterangan-keterangan yang berkaitan dalam bidang sintaksis. Dapatan analisis memperlihatkan pantun merupakan satu medium terbaik dalam menganalisis ayat-ayat bahasa Melayu kerana banyak perkataan digugurkan. Pengguguran perkataan berlaku kerana jumlah perkataan dalam pantun dan bentuk rima akhir terkawal atau dihadkan.
\end{abstract}

Kata kunci: Ayat majmuk pancangan, pantun Melayu, Teori Transformasi Generatif, proses transformasi, rajah pohon

Abstract This paper focuses on Malay conjuctive compound sentence used in Malay pantun. This study was based on a theory of Transformation Generative Grammar Standards applied in the Tatabahasa Dewan (2010). In producing conjuctive compound sentence occurs transformation processes like deletion, expansion and restructuring. Verse analysis is done based on the deep structure and surface structure with branching diagram and explanations related to the field of syntax. The findings of the analysis showed pantun is one of the best medium to analyze the syntax of the Malay language because many words were deleted. Word deletion occurs as the number of words in the rhymes and rhythms of the end of the controlled or restricted.

Keywords: Compound sentences, Malay pantun, Generative Theory of Transformation, transformation process, branching diagram 


\section{PENDAHULUAN}

Menurut Za'ba (1965:218-219), pantun merupakan karangan berangkap (puisi) kepunyaan masayarakat Melayu lama dan digunakan di kampungkampung untuk menggambarkan fikiran hiba sayu dan perasaan yang indah-indah seperti hal ehwal berkasih sayang dan pujuk rayu yang lemah lembut antara pasangan kekasih. Makalah ini dianggap berbeza kerana kebiasaannya, pantun Melayu hanya dilihat daripada aspek estetika seperti gaya bahasa, rentak serta irama yang dapat memberikan gambaran yang indah pada pantun.

Makalah ini membincangkan pantun dari aspek bahasa, iaitu binaan ayat majmuk pancangan yang melibatkan proses-proses transformasi, iaitu transformasi pengguguran, peluasan dan penyusunan semula yang berlaku dari struktur dalaman kepada struktur permukaan.

Walau bagaimanapun, makalah ini bukanlah perbincangan tentang teoritis Tatabahasa Transformasi Generatif (TG), sebaliknya diperlihatkan pelbagai corak dan pola penerbitan ayat dalam bahasa Melayu melalui spesifikasi rumus-rumus TG.

Binaan ayat majmuk banyak terdapat dalam pantun walaupun kebanyakannya pendek dan kompleks. Keadaan ini menimbulkan masalah, iaitu pembaca atau pendengar tidak memahami dengan jelas tentang binaan ayat majmuk walaupun mereka memahami maksud pantun yang dibaca atau diungkapkan. Justeru, binaan ayat majmuk yang kompleks ini perlu dianalisis dan dihuraikan untuk menunjukkan proses transformasi yang berlaku.

Bentuk binaan pantun dikatakan kompleks kerana dalam rangkap pantun banyak perkataan digugurkan. Pengguguran perkataan berlaku kerana jumlah perkataan dalam pantun dan bentuk rima akhir terkawal atau dihadkan. Susunan ayat majmuk yang kompleks ini memerlukan satu kajian lengkap.

Dalam pantun, sering kali berlaku proses pengguguran imbuhan kata kerja, penanda kata hubung dan pengguguran subjek ayat. Perkara ini menjadi suatu kelaziman dalam pantun-pantun Melayu. Selain daripada 
itu, terdapat juga penggunaan kata-kata singkatan yang dipengaruhi oleh bentuk pertuturan bahasa lisan. Bagaimanapun, ramai yang tidak menyedari bahawa pantun merupakan bahan terbaik untuk menganalisis ayat-ayat bahasa Melayu dan kajian sebegini agak jarang-jarang dilakukan. Oleh itu, kajian ini dijalankan bertujuan untuk:

a) mengenal pasti ayat majmuk pancangan yang terdapat dalam data, sama ada pada pembayang maksud atau maksud pantun.

b) Membincangkan struktur binaan ayat majmuk pancangan dalam pantun.

c) Menganalisis proses transformasi yang berlaku dalam binaan ayat majmuk pancangan.

\section{DATA KAJIAN}

Data-data yang digunakan dalam kajian ini diambil daripada buku Pantun Melayu terbitan Malaya Publishing House Limited Singapura yang dicetak pada tahun 1961. Buku ini disunting oleh tokoh terkemuka, iaitu R.J Wilkinson dan R.O Winstedt.

Bahan ini memuatkan sebanyak 1,244 rangkap pantun empat kerat dan setiap pantun terdiri daripada pembayang dan maksud. Buku ini dipilih kerana ia merupakan buku pantun Melayu terawal yang diterbitkan dan merangkumi pelbagai tema kehidupan masyarakat seperti perasaan hiba, suka, duka, sindiran, kasih sayang dan sebagainya. Antara contoh pantun yang dianalisis adalah seperti yang berikut:

722. Menimba berdebor-debor

Air ditimba di Kuala Kedah

Jangan abang cakap takbur

Unggas terbang dapat kugetah

1157. Tinggi bukit gunung Mabambar

Tempat bilal menaikkan khatib

Petang semalam mendapat khabar

Gunung Rembau digonggong pipit 
612. Buah berembang masak ranum Masak diperam dalam gua

Kumbang lalu bunga tersenyum

Belalang seekor tumpang ketawa

\section{Pergi ke pantai kutip belangkas}

Tambat kerbau di pohon belimbing

Hidup di dunia tiada berbingkas

Kalau bertunas diragut kambing

455. Kalau roboh kota Melaka

Papan Jawa saya dirikan

Kalau sungguh bagai dikata

Nyawa di badan saya serahkan

\section{Bentang tikar lebar-lebar}

Supaya senang tidur merampai

Kalau tuan bersawah lebar

Carikan abang emping bertangkai

380. Hujan turun renyai-renyai Berteduh di bawah perahu

Panggil abang di dalam serunai

Panggil mulut orangkan tahu

\section{SOROTAN KAJIAN}

Kajian tentang aspek sintaksis dalam pantun Melayu masih kurang dilakukan. Tokoh yang giat mengkaji pantun Melayu daripada aspek sintaksis ialah Nik Safiah Karim dan Ab Razak Ab Karim. Nik Safiah Karim merupakan salah seorang tokoh yang mengkaji pantun daripada aspek sintaksis. Penulisan beliau bertajuk "Pantun Melayu: Satu Garapan Struktur Ayat" (1996), mengkaji pantun dari sudut struktur ayat. Beliau telah memperlihatkan keunikan pantun Melayu dari segi susunan, pilihan 
struktur dan binaan ayat mengikut peraturan tatabahasa bahasa Melayu. Beliau membincangkan aspek ayat dalam pantun seperti binaan dan pola ayat, susunan ayat songsang, ayat majmuk, ayat yang tidak lengkap dan jenis-jenis ayat.

Makalah ini melihat pantun sebagai karya yang unik dan dapat dikaji dari pelbagai sudut. Pantun Melayu bukan sahaja dapat dilihat dari aspek keindahan tetapi juga dari aspek tatabahasa bahasa Melayu dari segi susunan dan binaan ayat. Pantun Melayu dilihat dapat mengeksploitasi segala kemungkinan binaan ayat Melayu untuk menyampaikan maksud dengan seindahnya.

Nik Safiah Karim (1997) dalam makalah "Keindahan Pantun Dari Sudut Sintaksis Bahasa Melayu" melihat keindahan pantun Melayu dari aspek bentuk, binaan dan keindahan pantun. Kebiasaannya, pantun Melayu dilihat dari aspek keindahan iaitu rentak dan irama, mesej yang hendak disampaikan dan hubungan antara pembayang maksud dengan maksudnya.

Dalam makalah ini, beliau menggunakan satu pendekatan lain bagi melihat unsur keindahan pantun Melayu, iaitu dari struktur ayat atau bidang sintaksis. Beliau menekankan bahawa aspek sintaksis turut berperanan menimbulkan unsur keindahan pantun Melayu. Aspek sintaksis memperlihatkan jenis ayat yang digunakan, binaan dan pola ayat, susunan konstituen ayat dan kelesenan berpuisi dan aspek-aspek perlanggaran hukum tatabahasa.

Ab. Razak Ab Karim (1996) melalui makalah "Pantun Melayu Lama: Analisis Penggunaan Kata dan Ayat" membincangkan tentang aspek bahasa, kata dan ayat yang membina sesebuah pantun. Dalam aspek kata, beliau menekankan penggunaan kata yang sering mengalami pengguguran imbuhan atau unsur-unsur tertentu yang menyebabkan kata-kata tanpa imbuhan banyak digunakan dalam pantun, terutama kata kerja.

Selain daripada itu, terdapat juga penggunaan kata-kata singkatan dan kata-kata arkaik. Kata-kata singkatan yang digunakan agak banyak 
dan penggunaannya dipengaruhi oleh bentuk pertuturan atau bahasa lisan. Keadaan ini disebabkan pengaruh suku kata yang amat penting dalam pantun Melayu.Terdapat juga penggunaan kata kerja dan kata sendi tetapi bilangannya hanya sedikit. Aspek ayat yang dibincangkan ialah ayat tanya, ayat tunggal dan ayat majmuk. Beliau juga turut membincangkan proses pembentukan ayat-ayat tersebut dalam struktur permukaan mengikut Tatabahasa Transformasi Generatif yang mengemukakan proses pengguguran, penyusunan semula dan peluasan sebagai proses transformasi dalam ayat.

Ab. Razak Ab Karim (2011) dalam makalah berjudul "Pantun Melayu Lama: Sumber Terbaik Pengajaran Sintaksis Bahasa Melayu" membincangkan pelbagai bentuk ayat yang digunakan dalam pantun Melayu. Kepelbagaian bentuk dan binaan ayat yang digunakan dalam pantun menggambarkan kebijaksanaan masyarakat Melayu. Kebijaksanaan ini jelas dilihat dalam menyusun ayat-ayat yang panjang tetapi dalam bentuk yang ringkas dan dapat difahami oleh pembaca. Aspek ayat yang akan disentuh ialah ayat tanya, ayat tunggal, ayat majmuk dan proses pembentukan ayat seperti proses pengguguran, proses penyusunan semula dan proses peluasan.

\section{METODOLOGI PENYELIDIKAN}

Kajian ini dilakukan dengan menganalisis sampel-sampel pantun yang sesuai yang telah mengalami proses transformasi daripada ayat intinya dengan menggunakan analisis Transformasi Generatif (TG). Kaedah ini dilakukan dengan mencerakinkan setiap konstituen ayat bagi menentukan binaannya. Analisis dibuat dengan menggunakan teknik rajah pohon (RP). Teknik ini digunakan untuk menunjukkan hubungan secara terperinci antara konstituen-konstituen dalam sesuatu ayat. Seterusnya, huraian dilakukan untuk membuktikan dapatan kajian ini.

\section{Kerangka Teori}

TG merupakan satu bidang analisis bahasa yang dikaitkan dengan proses kognitif. Proses ini menghubungkan realiti mental dengan pelahiran bahasa 
yang kreatif serta bersifat semula jadi. Chomsky telah mengemukakan dua konsep penting, iaitu kecekapan bahasa (language competence) dan perlakuan bahasa (language performance). Kecekapan bahasa yang terhasil daripada proses kognitif ini memungkinkan kita menerbitkan (to generate) dan memahami ayat-ayat yang tidak terhad jumlahnya. Kebolehan menerbitkan dan memahami ayat-ayat ini disebut oleh Chomsky sebagai perlakuan bahasa (language performance). Namun demikian, kecekapan bahasa dan perlakuan bahasa berkembang dalam hala tuju yang berbeza.

Teori TG telah berkembang dan mendapat perhatian dalam kalangan sarjana bahasa. Teori ini bermula sewaktu Chomsky menghuraikan teori standard seperti yang terdapat dalam Syntactic Structures (1957) dan penambahbaikannya dalam Aspects of the Theory of Syntax (1965). Teori ini kemudiannya berkembang kepada Extended Standard Theory (EST) atau Teori Standard Tambahan (1970) dan juga perubahan-perubahan yang terkini melalui pendekatan program Minimalis (1992).

Dalam aliran tatabahasa generatif (TG), aspek yang diberi tumpuan ialah bidang sintaksis, dengan bahagian-bahagian fonologi dan semantik, iaitu makna sebagai komponen sampingan. Dasar utama teori ini ialah anggapan bahawa setiap ayat yang dihasilkan sebenarnya mengandungi dua peringkat, iaitu struktur dalaman dan struktur permukaan.

Struktur dalaman ialah struktur yang mengandungi ayat dasar atau ayat inti yang diperlukan untuk memberikan semantik ayat, yang biasanya mengandungi bentuk dasar yang diperluas untuk asas makna ayat (Nik Safiah Karim et al., 1989:201). Dalam proses ini, ayat-ayat pada peringkat struktur dalaman diterbitkan daripada rumus struktur frasa. Peringkat struktur permukaan ialah struktur ayat yang biasanya telah mengalami perubahan daripada struktur dalaman. Struktur ini merupakan bentuk ayat yang sebenarnya dituturkan oleh seseorang penutur dan direalisasikan sebutannya oleh bahagian bunyi bahasa, iaitu komponen fonologi.

Apabila terdapat suatu ayat daripada jenis struktur permukaan yang berasal daripada dua struktur dalaman atau lebih, maka akan wujud ketaksaan ayat. Apabila terdapat dua jenis ayat permukaan yang berasal 
daripada hanya satu struktur dalaman, maka akan berlaku pula ayat-ayat yang bersifat parafrasa. Struktur dalaman bertanggungjawab kepada interpretasi makna, dan struktur permukaan pula diterbitkan daripada struktur dalaman melalui transformasi-transformasi tertentu.

Ketaksaan ayat bermaksud ayat yang tidak pasti maknanya, yang mempunyai lebih daripada satu makna. Sebagai contoh, ayat Ibu bapa Ali telah meninggal dunia. Ayat ini dapat diertikan Ibu kepada bapa (nenek Ali) telah meninggal dunia atau Kedua-dua ibu bapa Ali telah meninggal dunia. Dalam hal ini, intonasi dan jeda memainkan peranan sebagai penentu kepada maksud yang didukung oleh ayat. Ayat yang berparafrasa ialah dua ayat atau lebih yang membawa maksud yang sama walaupun susunan perkataan dalam ayat itu berbeza. Ayat yang berparafrasa dapat dilihat dalam ayat aktif dan ayat pasif. Ayat aktif yang telah dipasifkan berparafrasa dengan ayat aktif. Contohnya, ayat Ali memandu kereta itu dan Kereta itu dipandu Ali dianggap berparafrasa.

Mengikut hukum TG, struktur dalaman dan struktur permukaan diterbitkan oleh dua jenis hukum atau rumus tatabahasa. Rumus-rumus tersebut ialah Rumus Struktur Frasa (RSF) dan Rumus Transformasi. RSF membentuk ayat pada struktur dalaman, manakala Rumus Transformasi pula akan menukarkan pola atau struktur ayat-ayat hingga membawa kepada peringkat permukaan. Teori ini mengandaikan bahawa kedua-dua jenis rumus tatabahasa ini menjadi sebahagian daripada unsur kecekapan berbahasa seseorang individu.

Ayat-ayat yang terhasil daripada bentuk tersebut biasanya tidak mempunyai persamaan. Ayat yang terhasil daripada struktur dalaman akan menjadi input kepada pembentukan ayat pada peringkat permukaan. Penerbitan sesuatu ayat sebagai struktur permukaan berpunca daripada suatu ayat yang lain, kecuali ayat itu memang ayat dasar. Ayat yang bersifat demikian wujud pada peringkat struktur dalaman atau struktur dasar, dan wujud dalam bentuk yang serupa pada peringkat struktur permukaan. 
Model teori yang digunakan dapat digambarkan seperti yang berikut (Tatabahasa Dewan, 2010:534):

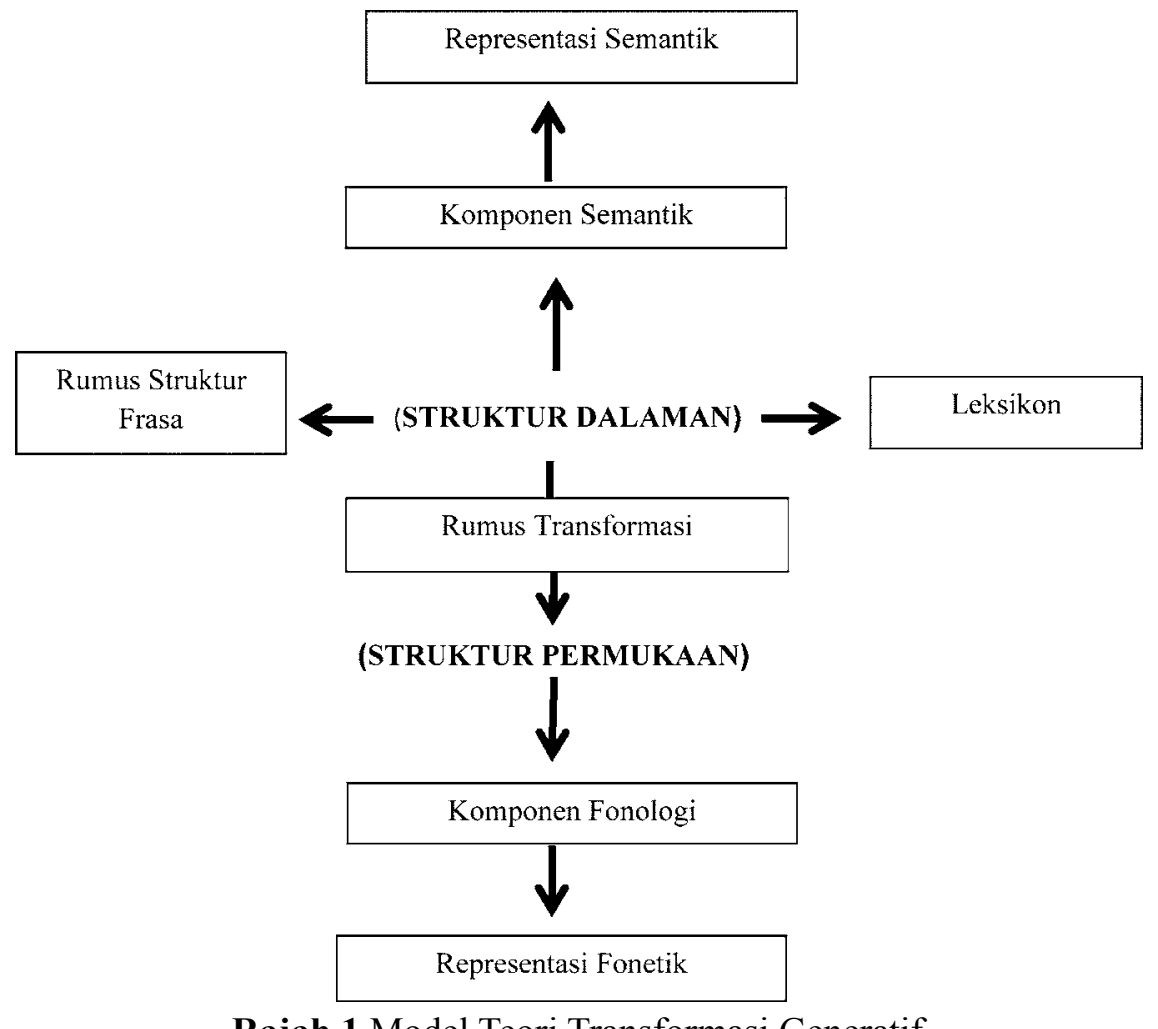

Rajah 1 Model Teori Transformasi Generatif

(Tatabahasa Dewan, 2010: 534)

\section{Ayat Majmuk Pancangan dalam Pantun Melayu}

Ayat majmuk pancangan ialah binaan ayat yang terdiri daripada satu ayat utama atau ayat induk dan satu atau beberapa ayat kecil lain yang dipancangkan dalam ayat induk dan menjadi sebahagian daripada ayat induk itu. 


\section{Ayat Majmuk Pancangan Relatif}

Ayat majmuk pancangan relatif terdiri daripada satu klausa bebas atau ayat utama dan satu klausa terikat atau klausa kecil atau lebih. Dalam ayat ini, ayat kecil dipancangkan ke dalam subjek ayat utama atau predikat ayat utama dengan menggunakan kata hubung. Binaan ayat ini seperti berikut:

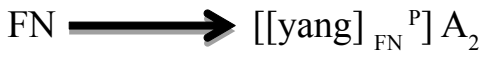

(FN) ialah (FN) sebahagian daripada rumus yang menerangkan binaan FN dalam bahasa Melayu. Unsur pilihan $\mathrm{A}_{2}$ yang mengikuti $\mathrm{KN}$ ialah ayat relatif.

Ayat relatif ialah ayat yang ditandai dengan penggunaan kata hubung relatifyang. Namun demikian, jarang ditemui penggunaan kata relatif yang dalam pantun dan biasanya kata relatif ini mengalami pengguguran. Antara contoh pantun yang menggunakan ayat majmuk pancangan dengan kata hubung yang adalah seperti pantun yang berikut:

722 $2^{1}$ Menimba berdebor-debor

Air ditimba di Kuala Kedah

Jangan abang cakap takbur

Unggas terbang dapat kugetah

Dalam pantun 772, penggunaan ayat majmuk pancangan relatif dapat dikesan pada maksud pantun, iaitu dalam baris keempat. Dalam maksud pantun ini, struktur dalaman binaan ayatnya adalah seperti yang berikut:

S-D: Unggas yang terbang dapat aku getah.

Ayat ini terdiri daripada dua ayat tunggal yang menjadi binaannya, iaitu:

a) Unggas

terbang.

FN

FK

b) Unggas

dapat kugetah.

FN

FK 
Berdasarkan pantun di atas, dalam baris keempat pantun ini terdapat penggunaan ayat majmuk pancangan relatif dengan penggunaan kata relatif yang telah digugurkan. Struktur dalaman ayat ini setelah mengalami pengguguran dan ayat yang terhasil dalam struktur permukaan ditunjukkan seperti yang berikut:

S-P: Unggas terbang dapat kugetah.

Ayat kedua merupakan ayat kecil yang dipancangkan dalam ayat induk dan kata pancangan relatif yang digunakan dalam ayat ini. Proses pemancangan menyebabkan berlaku pengguguran subjek ayat kedua. Binaan ayat dalam struktur dalaman ditunjukkan seperti rajah pohon di bawah:

\section{$\underline{\text { Rajah Pohon S-D }}$}

a)

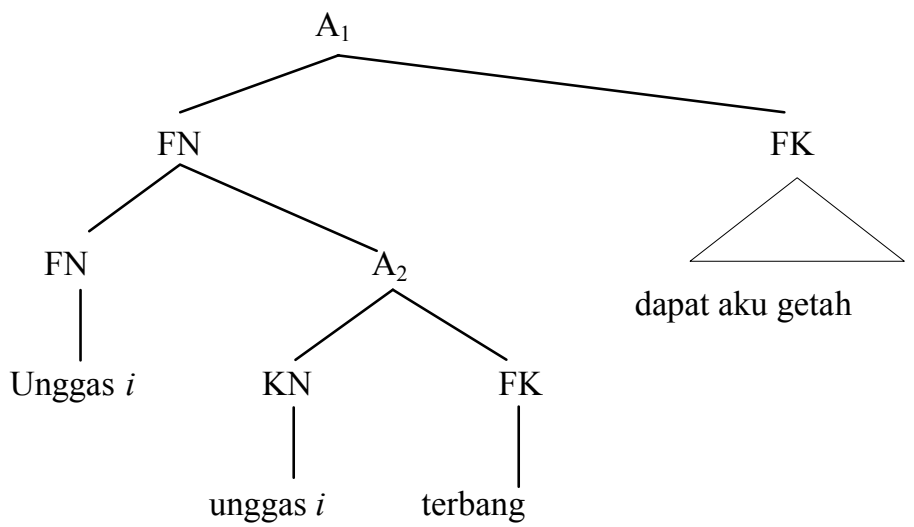

Pola binaan $\mathrm{A}_{1}$ dan $\mathrm{A}_{2}$ ialah subjek dan predikat yang terdiri daripada binaan frasa nama dan frasa kerja. Konstituen frasa nama $\mathrm{A}_{1}$ ialah unggas, manakala konstituen predikatnya ialah terbang. Frasa nama dalam subjek $\mathrm{A}_{2}$ sama dengan frasa nama $\mathrm{A}_{1}$ iaitu unggas, manakala frasa kerja dalam $\mathrm{A}_{2}$ ialah dapat kugetah.

Kedua-dua ayat tunggal ini mempunyai subjek yang sama, iaitu unggas yang mempunyai dua frasa kerja terbang dan kugetah. Dalam pembentukan ayat pancangan relatif, subjek yang sama dalam ayat kecil digugurkan dan digantikan dengan kata pancangan relatif yang. Ayat ini dalam struktur permukaan ditunjukkan seperti dalam rajah di bawah: 
b)

\section{Rajah Pohon S-P}

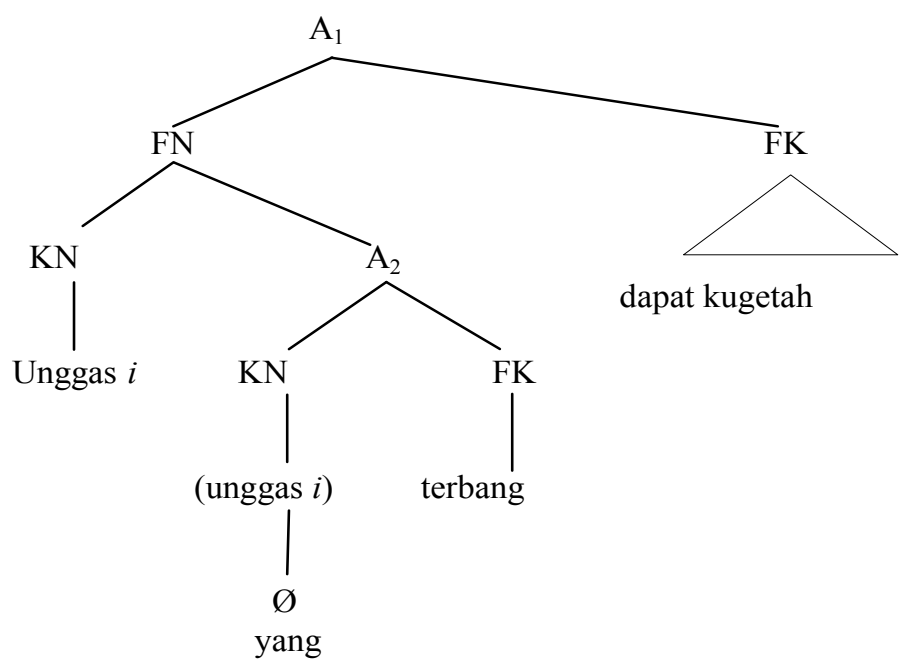

$\mathrm{A}_{2}$ merupakan ayat kecil dipancangkan dalam ayat induk, iaitu $\mathrm{A}_{1}$ dan kata pancangan yang digunakan dalam ayat ini. Dalam pantun ini, $\mathrm{A}_{1}$ unggas terbang dipancangkan ke dalam $\mathrm{A}_{2}$, iaitu unggas dapat kugetah. Oleh sebab frasa nama unggas diulang, maka frasa nama $\mathrm{A}_{2}$ yang sama digugurkan dan diganti dengan kata relatif yang. Dalam struktur permukaan pantun ini, pengguguran berlaku ke atas kata hubungan pancangan keterangan yang.

Binaan ayat dalam baris keempat pantun ini merupakan binaan ayat pasif dengan kata ganti nama diri pertama. Bagi bentuk ayat pasif ini, kata ganti nama diri diletakkan di hadapan kata kerja dasar. Hal ini demikian kerana $\mathrm{KGN}_{1}$ dan $\mathrm{KGN}_{2}$ tidak boleh menerima kata kerja dengan imbuhan pasif $d i$-. $\mathrm{KGN}_{1}$ dan $\mathrm{KGN}_{2}$ yang hadir di hadapan kata kerja dasar boleh berbentuk kata penuh atau kata singkatan. Dalam ayat ini, kata ganti nama aku diringkaskan menjadi $-k u$.

Berdasarkan analisis yang dilakukan, ayat ini merupakan ayat majmuk pancangan relatif dengan kata pancangan yang. Dalam ayat ini berlaku proses transformasi pengguguran, iaitu pengguguran kata hubung pancangan relatif yang dan subjek kata nama dalam ayat kedua, iaitu unggas. Transformasi relatif yang berlaku dalam ayat ini berfungsi sebagai penerang kepada frasa nama sahaja. 


\section{Ayat Majmuk Pancangan Komplemen}

Ayat komplemen bahasa Melayu dihuraikan dalam bentuk rumus seperti yang berikut (Hashim Musa, 1989: 83):

$$
\tilde{\mathrm{A}} \text { (komp) } \mathrm{A}_{2}
$$

Rumus ini menyatakan bahawa Ã yang berfungsi sebagai ayat komplemen terdiri daripada $\mathrm{A}_{2}$ yang secara opsyenal didahului oleh kata komplemen. Ayat komplemen ini pula dipancangkan ke dalam FN atau FK ayat induk. Proses yang berlaku apabila penggabungan dua ayat ini dinamakan transformasi komplementasi.

Antara contoh pantun yang menggunakan ayat majmuk pancangan komplemen adalah seperti pantun yang berikut:

\section{Tinggi bukit gunung Mabambar}

Tempat bilal menaikkan khatib

\section{Petang semalam mendapat khabar \\ Gunung Rembau digonggong pipit}

Dalam pantun ini, ayat ketiga dan keempat merupakan ayat majmuk pancangan komplemen. Dalam maksud pantun ini, struktur dalaman binaan ayatnya adalah seperti yang berikut:

S-D: Saya mendapat khabar petang semalam bahawa pipit menggongong Gunung Rembau.

Ayat ini terdiri daripada dua ayat tunggal yang menjadi binaannya, iaitu:

a) Saya mendapat khabar petang semalam.

FK

FK

b) Gunung Rembau

FN

digonggong pipit.

FK

Binaan ayat $\mathrm{A}_{1}$ dan $\mathrm{A}_{2}$ merupakan ayat majmuk pancangan komplemen dengan unsur keterangan dan objek. Binaan ayat dalam struktur dalaman ditunjukkan seperti rajah pohon di bawah: 


\section{$\underline{\text { Rajah Pohon S-D }}$}

a)

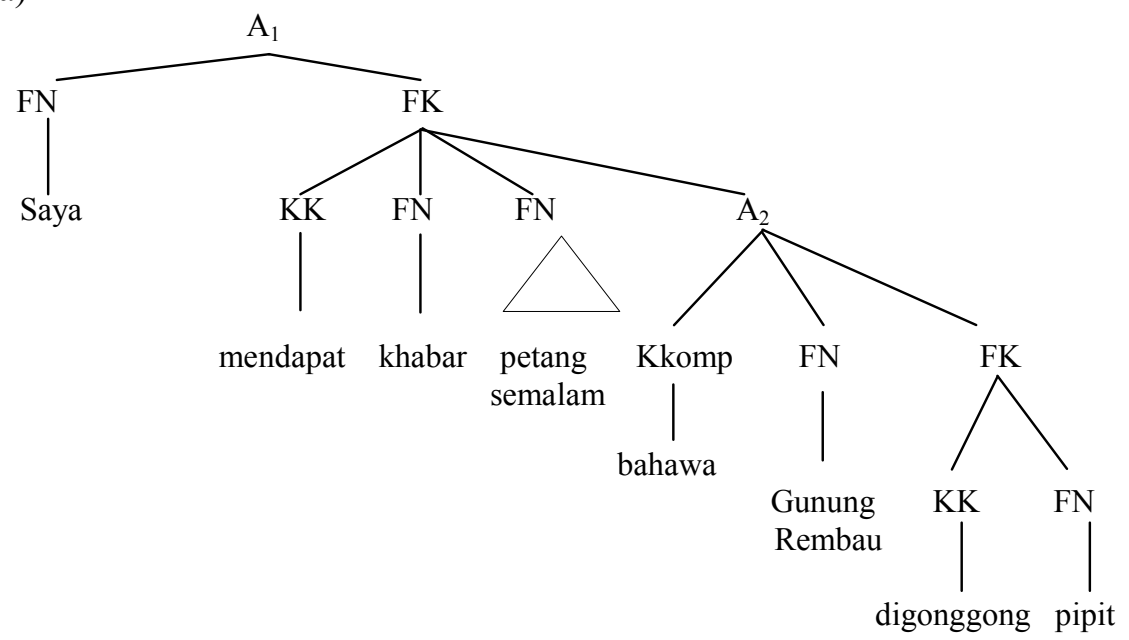

Pola $\mathrm{A}_{1}$ berdasarkan binaan subjek dan predikat. Subjek $\mathrm{A}_{1}$ ialah saya, manakala predikatnya ialah mendapat khabar petang semalam. Frasa kerja dalam predikat ayat ini ialah mendapat dan objek, iaitu frasa nama, ialah khabar. Unsur keterangan, iaitu frasa sendi nama, hadir selepas kata kerja, iaitu petang semalam. Dalam struktur permukaan, subjek $\mathrm{A}_{1}$ telah digugurkan.

Pola $A_{2}$ terdiri daripada binaan subjek, iaitu frasa nama dan predikatnya pula frasa kerja. Subjek $\mathrm{A}_{2}$ ialah Gunung Rembau, manakala predikatnya kata kerja pasif digonggong. Ayat ini merupakan ayat pasif yang diikuti objek, iaitu pipit. Kedua-dua ayat ini digabungkan dengan kata komplemen bahawa untuk membentuk ayat komplemen.

Dalam struktur permukaan juga berlaku proses pengguguran subjek kata ganti nama, iaitu saya/anda dalam A Ayat S-D ini mengalami proses transformasi seperti yang ditunjukkan dalam rajah di bawah: 


\section{$\underline{\text { Rajah Pohon S-P }}$}

b)

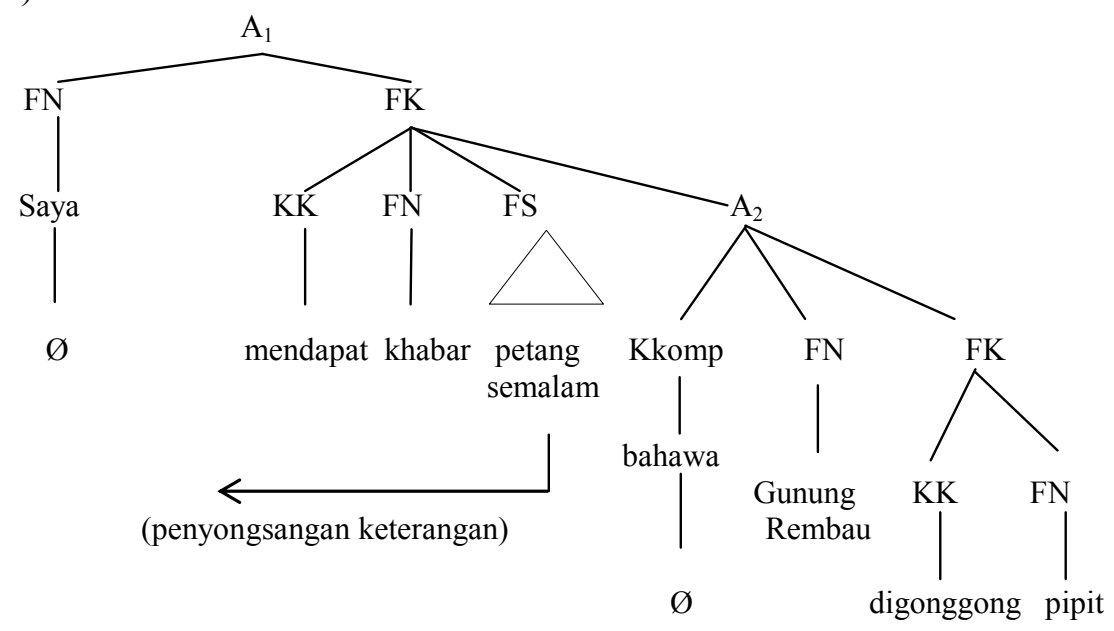

Binaan $\mathrm{A}_{1}$ telah mengalami proses pendepanan sebahagian predikat. Proses pendepanan yang berlaku ialah pendepanan unsur keterangan, iaitu petang semalam. Dalam struktur dalaman, unsur keterangan petang semalam berada dalam frasa predikat tetapi dalam struktur permukaan, frasa ini disongsangkan ke hadapan. Apabila dua frasa ini disusun semula, frasa ini akan menjadi saya mendapat khabar petang semalam.

Berdasarkan dua ayat di atas, $A_{1}$ merupakan ayat induk dan $A_{2}$ merupakan ayat kecil yang akan dipancangkan ke dalam ayat induk melalui proses komplementasi. Dalam struktur permukaan, kata komplemen bahawa yang menggabungkan ayat induk dan ayat kecil ini digugurkan.

Berdasarkan analisis yang telah dilakukan dalam pantun ini, ayat ini merupakan ayat komplemen yang mengandungi kata hubung komplemen bahawa. Walau bagaimanapun, kata komplemen ini digugurkan dalam struktur permukaan. Dalam bahasa Melayu, pengguguran ini dibenarkan sekiranya tidak menjejaskan makna ayat. 


\section{Ayat Majmuk Pancangan Keterangan}

Ayat majmuk keterangan ialah ayat majmuk yang terdiri daripada satu ayat induk dan satu ayat kecil atau lebih yang berfungsi sebagai keterangan kepada predikat.

Ayat keterangan bahasa Melayu dihuraikan dalam bentuk rumus seperti yang berikut (Hashim Musa, 1989: 32)

\section{$\mathrm{KET} \longrightarrow$ Hubung Panc $\mathrm{A}_{2}$}

Rumus ini menyatakan bahawa unsur klausa keterangan (KET) boleh dibentuk oleh dua unsur, iaitu kata hubungan pancangan (Hubung Panc) dan $\mathrm{A}_{2}$, iaitu ayat pancangan. Klausa keterangan merupakan unsur yang menerangkan seluruh predikat, iaitu predikat-predikatnya FN, FA, FS dan FK dan KET mengandungi ayat pancangan $\left(\mathrm{A}_{2}\right)$ yang dipancangkan ke dalam ayat induk melalui penggunaan kata hubung pancangan.

\section{Ayat Majmuk Keterangan Musabab}

Keterangan musabab ialah unsur yang menerangkan sebab berlaku sesuatu kejadian atau perbuatan. Kata hubung keterangan musabab adalah seperti kerana, lantaran dan oleh sebab. Antara contoh pantun yang menggunakan ayat majmuk keterangan musabab adalah seperti pantun yang berikut:

\section{Buah berembang masak ranum Masak diperam dalam gua}

Kumbang lalu bunga tersenyum

Belalang seekor tumpang ketawa

Dalam pembayang maksud ini, struktur dalaman binaan ayatnya adalah seperti yang berikut:

S-D: Buah berembang masak ranum kerana diperam di dalam gua.

Dalam pantun ini, terdapat dua ayat tunggal yang terdiri daripada ayatayat berikut: 
a) Buah berembang FN

b) Buah berembang FN masak ranum.

FK

diperam di dalam gua.

FK

Struktur dalaman ayat ini setelah mengalami peleburan dan ayat yang terhasil dalam struktur permukaan adalah seperti yang berikut:

S-P: Buah berembang masak ranum, masak diperam dalam gua.

Binaan ayat dalam struktur dalaman ditunjukkan seperti rajah pohon di bawah:

\section{$\underline{\text { Rajah Pohon S-D }}$}

a)

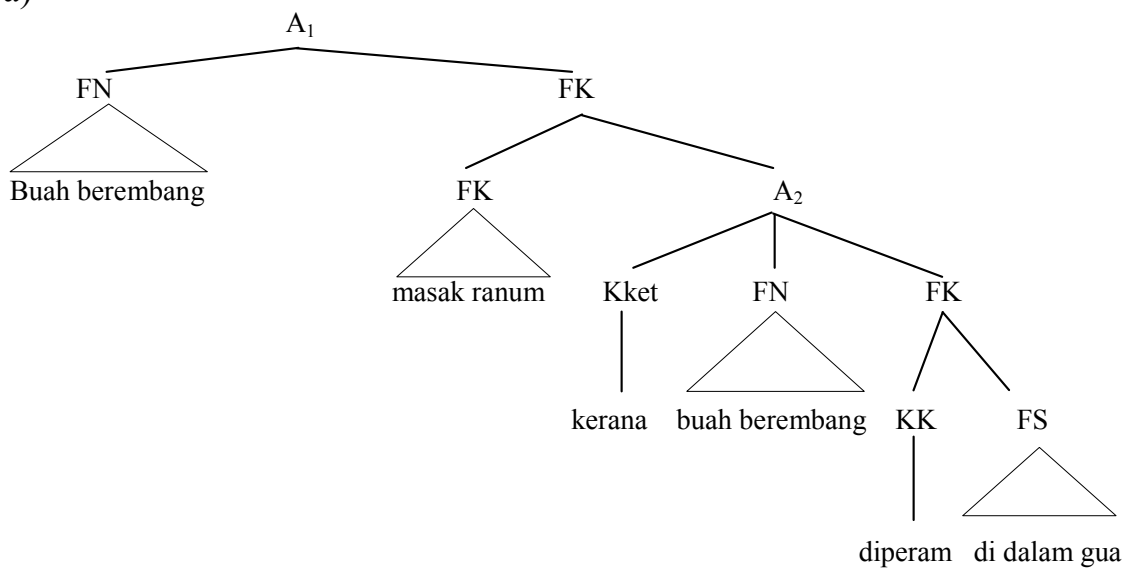

Pola $\mathrm{A}_{1}$ dan $\mathrm{A}_{2}$ terdiri daripada binaan subjek dan predikat. Subjek dalam kedua-dua ayat ini terdiri daripada frasa nama, iaitu buah berembang, manakala predikatnya ialah frasa kerja. Predikat $\mathrm{A}_{1}$ terdiri daripada frasa adjektif, iaitu masak ranum, manakala predikat $\mathrm{A}_{2}$ terdiri daripada frasa kerja, iaitu diperam. Unsur keterangan di dalam gua juga hadir dalam $\mathrm{A}_{2}$ binaan pantun ini.

Dalam struktur dalaman berlaku proses pengguguran subjek kata nama, iaitu buah berembang dalam $\mathrm{A}_{2}$ kerana frasa nama dalam $\mathrm{A}_{1}$ dan $\mathrm{A}_{2}$ adalah sama. Sekiranya frasa tersebut disusun semula setelah berlaku pengguguran frasa nama, frasa ini akan terdiri daripada konstituen Buah berembang masak ranum kerana diperam di dalam gua. 
Selain daripada itu, penanda kata hubung keterangan musabab dalam pantun telah digugurkan. Pengguguran ini berlaku kerana pembaca telah sedia maklum akan maksud pantun walaupun tanpa penggunaan kata hubung. Ayat S-D ini mengalami proses transformasi seperti yang ditunjukkan dalam rajah di bawah:

\section{$\underline{\text { Rajah Pohon S-P }}$}

b)

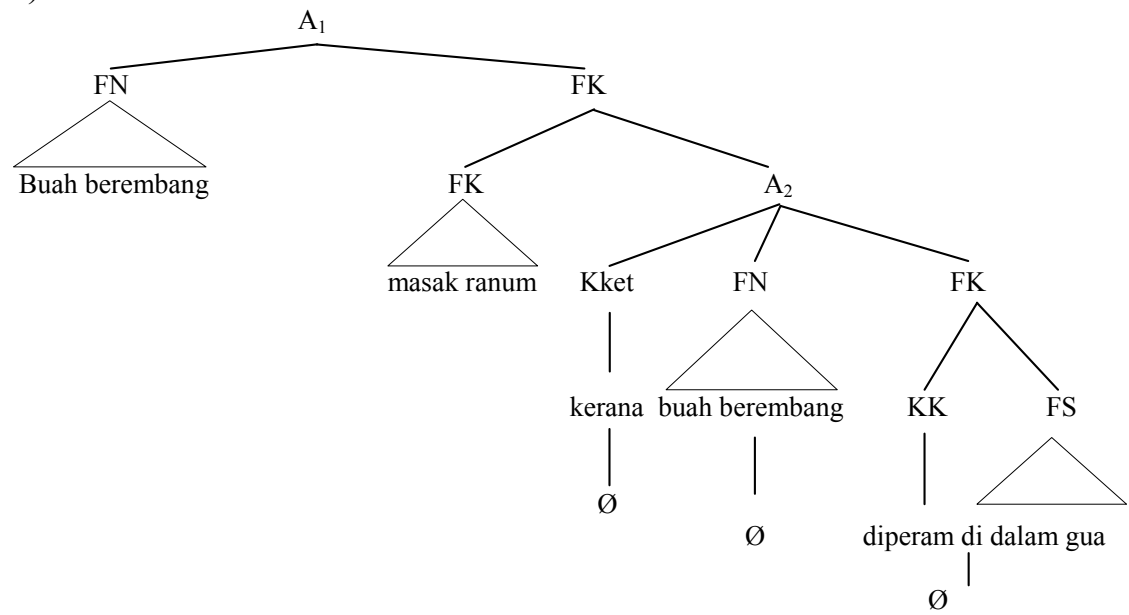

Binaan $\mathrm{A}_{1}$ dan $\mathrm{A}_{2}$ terdiri binaan subjek dan predikat. Kedua-dua ayat ini mempunyai subjek yang sama, iaitu buah berembang. Subjek dalam $\mathrm{A}_{2}$ digugurkan untuk membentuk dua frasa, iaitu masak ranum dan diperam di dalam gua. Binaan $\mathrm{A}_{1}$ dan $\mathrm{A}_{2}$ digabungkan dengan kehadiran kata hubung keterangan musabab, iaitu kerana.

Binaan $\mathrm{A}_{1}$ merupakan ayat aktif, manakala binaan $\mathrm{A}_{2}$ merupakan ayat pasif. Binaan $\mathrm{A}_{2}$ merupakan ayat pasif yang kata kerjanya mengandungi imbuhan kata kerja pasif di-, iaitu diperam.

Kata hubung keterangan musabab kerana yang digunakan dalam pantun telah mengalami proses pengguguran. Pengguguran ini berlaku kerana maksud ayat dalam pantun telah difahami. Keadaan ini memperlihatkan kecekapan penutur menyampaikan mesej tanpa mencacatkan struktur sintaksis dalam pantun. 


\section{Ayat Majmuk Keterangan Tujuan}

Keterangan tujuan ialah unsur yang menerangkan maksud bagi sesuatu perbuatan atau kejadian. Kata hubung keterangan tujuan adalah seperti untuk, demi dan bagi. Antara contoh pantun yang menggunakan ayat majmuk keterangan tujuan adalah seperti pantun yang berikut:

\section{Pergi ke pantai kutip belangkas}

Tambat kerbau di pohon belimbing

Hidup di dunia tiada berbingkas

Kalau bertunas diragut kambing

Dalam pembayang maksud ini, struktur dalaman binaan ayatnya adalah seperti yang berikut;

S-D: Tuan pergi ke pantai untuk mengutip belangkas.

Ayat ini terdiri daripada dua ayat tunggal yang menjadi binaannya, iaitu:

a) Tuan pergi ke pantai.

FN FK

b) Tuan mengutip belangkas.

FN FK

Dalam baris ketiga, subjek kata ganti nama telah mengalami proses pengguguran. Kedua-dua ayat tunggal ini mempunyai subjek yang sama, iaitu anda/tuan yang telah digugurkan. Dalam pembentukan ayat majmuk, subjek ayat yang sama akan digugurkan dan digantikan dengan kata hubung keterangan. Walau bagaimanapun, dalam pantun ini kata hubung keterangan juga telah mengalami pengguguran. Struktur dalaman ayat ini setelah mengalami peleburan adalah seperti yang berikut:

S-P: Pergi ke pantai kutip belangkas.

Binaan ayat dalam struktur dalaman ditunjukkan seperti rajah pohon di bawah: 


\section{$\underline{\text { Rajah Pohon S-D }}$}

a)

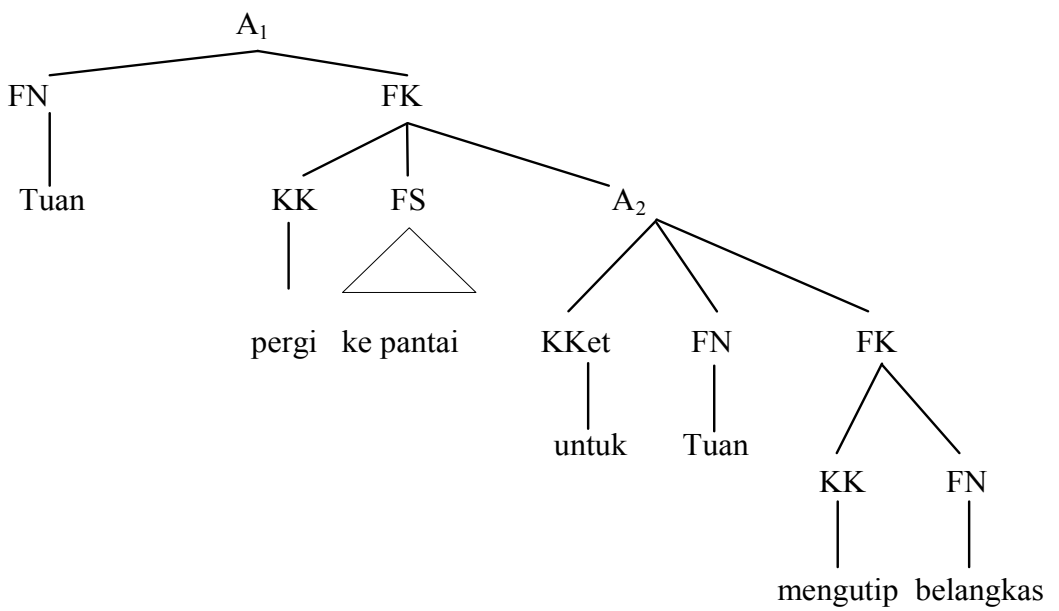

Binaan $A_{1}$ dan $A_{2}$ dibina berdasarkan binaan subjek frasa nama dan predikat frasa kerja. Frasa nama $\mathrm{A}_{1}$ ialah tuan, manakala frasa kerja ialah pergi ke pantai. Frasa sendi nama, iaitu ke pantai merupakan keterangan dalam $\mathrm{A}_{2}$. Binaan $\mathrm{A}_{2}$ merupakan ayat aktif transitif dengan kata kerja aktif, iaitu mengutip. Ayat aktif ini mempunyai objek yang terdiri daripada frasa nama, iaitu belangkas yang hadir selepas kata kerja.

Ayat S-D ini mengalami proses transformasi seperti yang ditunjukkan dalam rajah di bawah:

\section{$\underline{\text { Rajah Pohon S-P }}$}

b)

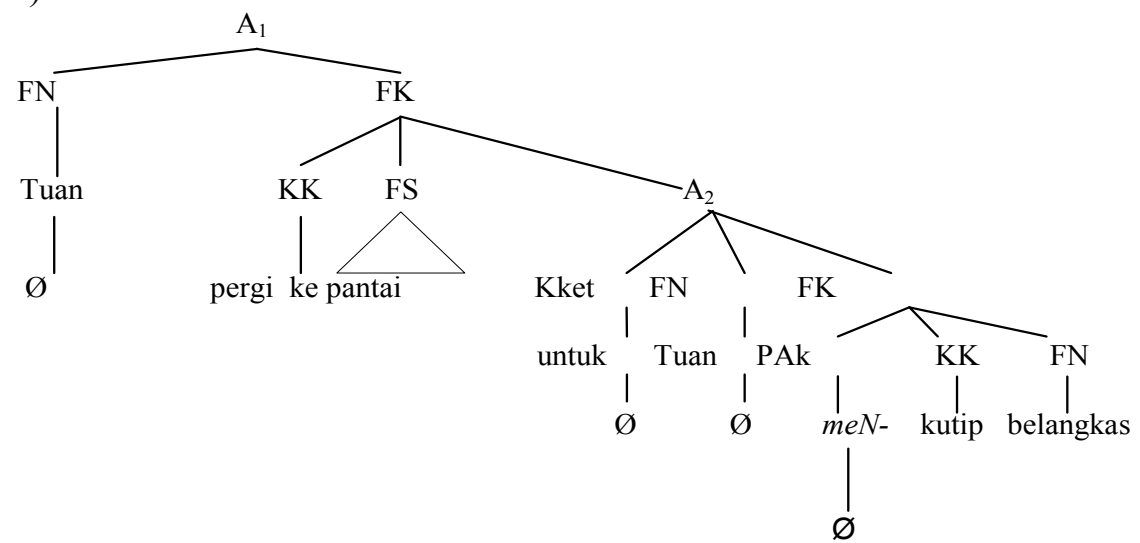


Binaan $A_{1}$ dan $A_{2}$ hanya terdiri daripada unsur predikat sahaja. Kedua-dua ayat ini mempunyai subjek yang sama, iaitu anda/tuan yang digugurkan untuk membentuk dua frasa kerja, iaitu pergi ke pantai dan mengutip belangkas. Binaan $\mathrm{A}_{1}$ dan $\mathrm{A}_{2}$ digabungkan dengan kehadiran kata hubung keterangan tujuan, iaitu untuk.

Dalam struktur permukaan $\mathrm{A}_{2}$, penanda kata kerja aktif $m e N$ - dalam kata kerja kutip mengalami peleburan seperti subjek ayat dan kata hubung. Imbuhan awalan meN- dalam kata kerja mengutip digugurkan menjadi kutip.

Kata hubung keterangan tujuan untuk yang digunakan dalam pantun telah mengalami proses pengguguran. Pengguguran ini berlaku kerana maksud ayat dalam pantun telah difahami. Keadaan ini memperlihatkan kecekapan penutur menyampaikan mesej tanpa mencacatkan struktur sintaksis dalam pantun.

Berdasarkan analisis yang dilakukan dalam baris ketiga pantun, berlaku proses pengguguran subjek kata ganti nama, kata hubung keterangan dan penanda awalan kata kerja. Walaupun binaan pantun di atas melanggar peraturan tatabahasa bahasa Melayu, tetapi boleh diberikan kelonggaran demi mempertahankan keindahan pantun.

\section{Ayat Majmuk Keterangan Syarat}

Keterangan syarat ialah unsur yang menerangkan tuntutan yang mesti dipenuhi. Kata hubung keterangan syarat adalah seperti sekiranya, andai kata, jikalau, jika dan kalau. Antara contoh pantun yang menggunakan ayat majmuk keterangan syarat adalah seperti pantun berikut:

\section{Kalau roboh kota Melaka \\ Papan Jawa saya dirikan}

Kalau sungguh bagai di kata

Nyawa di badan saya serahkan

Dalam pembayang maksud ini, struktur dalaman binaan ayatnya adalah seperti yang berikut: 
S-D: Kota Melaka saya dirikan dengan papan Jawa kalau kota Melaka roboh.

Ayat ini terdiri daripada dua ayat tunggal yang menjadi binaannya, iaitu:

a) Kota Melaka saya dirikan dengan papan Jawa.

FN FK

b) Kota Melaka roboh.

FN FK

Berdasarkan pantun di atas, terdapat beberapa proses transformasi yang berlaku. Dalam struktur permukaan, subjek dan penanda kata kerja pasif dalam $A_{1}$ telah digugurkan. Binaan ayat dalam struktur dalaman ditunjukkan seperti rajah pohon di bawah:

\section{Rajah Pohon S-D}

a)

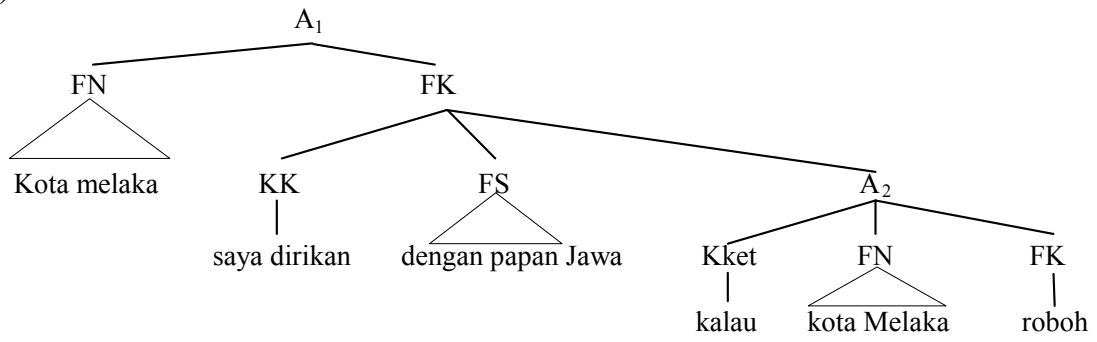

Pola binaan $\mathrm{A}_{1}$ ialah subjek dan predikat yang terdiri daripada binaan frasa nama dan frasa kerja. Konstituen frasa nama ayat ini ialah kota Melaka, manakala konstituen predikatnya ialah saya dirikan dengan papan Jawa. Pola $\mathrm{A}_{2}$ terdiri daripada binaan subjek frasa nama, manakala predikatnya terdiri daripada frasa kerja. Frasa nama dalam subjek $\mathrm{A}_{2}$ ialah kota Melaka manakala frasa kerja dalam $\mathrm{A}_{2}$ ialah roboh.

Berdasarkan contoh pantun ini didapati bahawa subjek dalam $\mathrm{A}_{1}$, iaitu kota Melaka telah digugurkan. Ayat ini dalam struktur permukaan adalah seperti rajah di bawah: 


\section{Rajah Pohon S-P}

b)

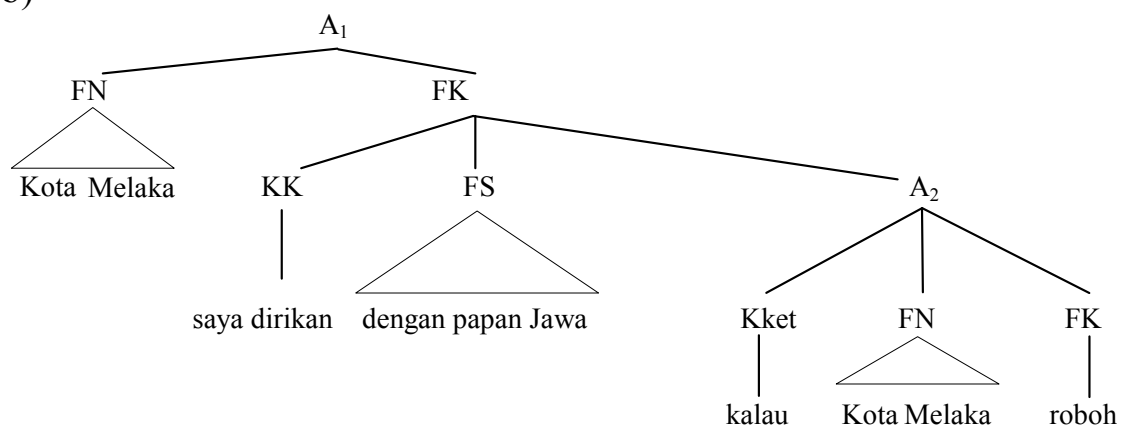

Dalam struktur permukaan, binaan $\mathrm{A}_{1}$ merupakan binaan ayat pasif dan $\mathrm{A}_{2}$ merupakan binaan ayat songsang. Binaan $\mathrm{A}_{1}$ merupakan binaan ayat pasif dengan kata ganti diri orang pertama dan kedua. Dalam $\mathrm{A}_{1}$, kata ganti diri pertama, iaitu saya diletakkan di hadapan kata kerja dasar dirikan. Binaan $\mathrm{A}_{2}$ merupakan binaan ayat songsang, iaitu pendepanan seluruh predikat.

Dalam struktur dalaman $\mathrm{A}_{1}$, keterangan cara dengan papan Jawa sepatutnya hadir di belakang ayat induk. Dalam ayat ini, unsur keterangan tersebut hendak difokuskan, dan berlaku proses penyusunan semula. Unsur keterangan ini diletakkan di hadapan ayat menjadi dengan papan Jawa saya dirikan. Namun demikian, kata hubung keterangan dengan telah digugurkan dalam pantun ini. Dalam baris ini, terdapat juga pengguguran subjek ayat dan subjek ini telah dinyatakan dalam baris pertama pantun, iaitu kota Melaka.

Dalam struktur dalaman $\mathrm{A}_{2}$, frasa kerja roboh terletak dalam frasa predikat tetapi dalam struktur permukaan, frasa ini disongsangkan ke hadapan dan berfungsi sebagai subjek. Binaan ayat ini telah mengalami proses pendepanan frasa predikat, iaitu roboh. Proses pendepanan yang berlaku ialah pendepanan seluruh frasa predikat, iaitu frasa kerja dan pendepanan unsur keterangan. Proses pendepanan yang berlaku bertujuan untuk memberi penekanan pada kata roboh dalam bentuk bahasa lisan. 
Dalam pantun 455, baris kedua dalam pembayang maksud mengalami pengguguran imbuhan kata kerjanya. Dalam baris kedua, kata dirikan sepatutnya menjadi mendirikan apabila awalan meN- dicantumkan pada kata dasar tersebut. Apabila kata dasar yang diberi imbuhan dan juga objek ayat ini dimasukkan, akan terhasillah ayat Saya mendirikan Kota Melaka dengan papan Jawa. Frasa dengan papan Jawa berfungsi sebagai keterangan dalam ayat tersebut.

Berdasarkan analisis yang dilakukan, ayat majmuk keterangan dalam pantun di atas telah mengalami proses pengguguran subjek dalam $A_{1}$, pengguguran kata keterangan dan proses pendepanan seluruh frasa kerja predikat. Walaupun binaan ayat ini mengalami proses transformasi, tetapi masih boleh difahami oleh anggota masyarakat yang sering menggunakan pantun.

\section{Ayat Majmuk Keterangan Harapan}

Keterangan harapan ialah unsur yang menerangkan sesuatu perbuatan atau kejadian yang dihajati. Kata hubung keterangan harapan adalah seperti supaya, agar, semoga, moga-moga dan kalau-kalau. Antara contoh pantun yang menggunakan kata hubung keterangan harapan supaya ialah:

\section{Bentang tikar lebar-lebar Supaya senang tidur merampai}

Kalau tuan bersawah lebar

Carikan abang emping bertangkai

Proses transformasi pantun di atas berlaku pada pembayang maksud pantun. Struktur dalaman binaan ayatnya adalah seperti yang berikut:

S-D: Tuan membentang tikar lebar-lebar supaya senang tidur merampai.

Ayat majmuk ini dari segi binaannya terdiri daripada ayat-ayat tunggal seperti yang berikut: 
a) Tuan membentang tikar lebar-lebar.

F N FK

b) Tuan senang tidur merampai.

F N FK

Ayat di atas mempunyai keterangan yang terdiri daripada kata hubung supaya yang diikuti oleh $\mathrm{A}_{2}$. Struktur dalaman ayat ini setelah mengalami peleburan dan ayat yang terhasil dalam struktur permukaan adalah seperti yang berikut:

S-P: Bentang tikar lebar-lebar supaya tuan senang tidur merampai.

Apabila kedua-dua ayat ini bergabung, berlaku proses pancangan dan kata keterangan harapan supaya digunakan sebagai kata pancangan dalam ayat majmuk ini. Binaan ayat dalam struktur dalaman ditunjukkan seperti rajah pohon di bawah:

\section{Rajah Pohon S-D}

a)

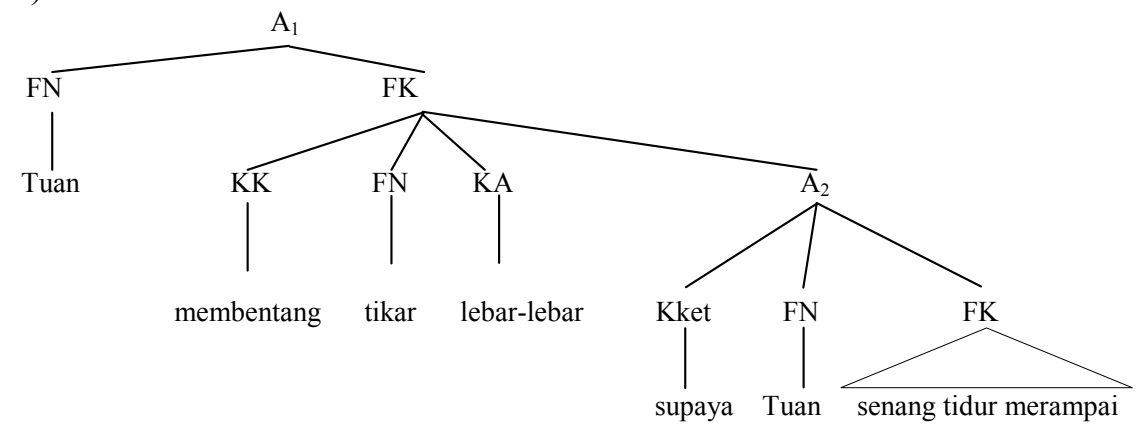

Pola $A_{1}$ terdiri daripada binaan subjek dan predikat iaitu, frasa nama dan frasa kerja. Konstituen frasa nama ayat ini ialah tuan, manakala konstituen predikatnya ialah membentang tikar lebar-lebar. Binaan predikat terdiri daripada kata kerja, iaitu membentang dan objek tikar.

Pola $\mathrm{A}_{2}$ juga terdiri daripada binaan subjek frasa nama, manakala predikatnya frasa kerja. Frasa nama dalam subjek $\mathrm{A}_{2}$ sama dengan $\mathrm{A}_{2}$, iaitu tuan manakala frasa kerja dalam $\mathrm{A}_{2}$ ialah senang tidur merampai. Binaan 
frasa predikat terdiri daripada kata kerja tak transitif yang diikuti oleh unsur keterangan, iaitu tidur merampai. Frasa senang dalam ayat ini membawa maksud mudah.

Dalam pantun ini, kata hubung keterangan supaya yang menggabungkan $\mathrm{A}_{1}$ dan $\mathrm{A}_{2}$ wujud dalam struktur permukaan. Kehadiran kata hubung dalam pantun jarang berlaku kerana kebiasaannya kata hubung akan digugurkan. Kehadiran kata hubung supaya membolehkan keterangan dalam kecil menimbulkan maksud harapan kepada predikat ayat induk. Keterangan tersebut menerangkan perbuatan membentang tikar lebar-lebar agar senang tidur merampai.

Ayat S-D ini mengalami proses transformasi seperti yang ditunjukkan dalam rajah di bawah:

\section{$\underline{\text { Rajah Pohon S-P }}$}

b)

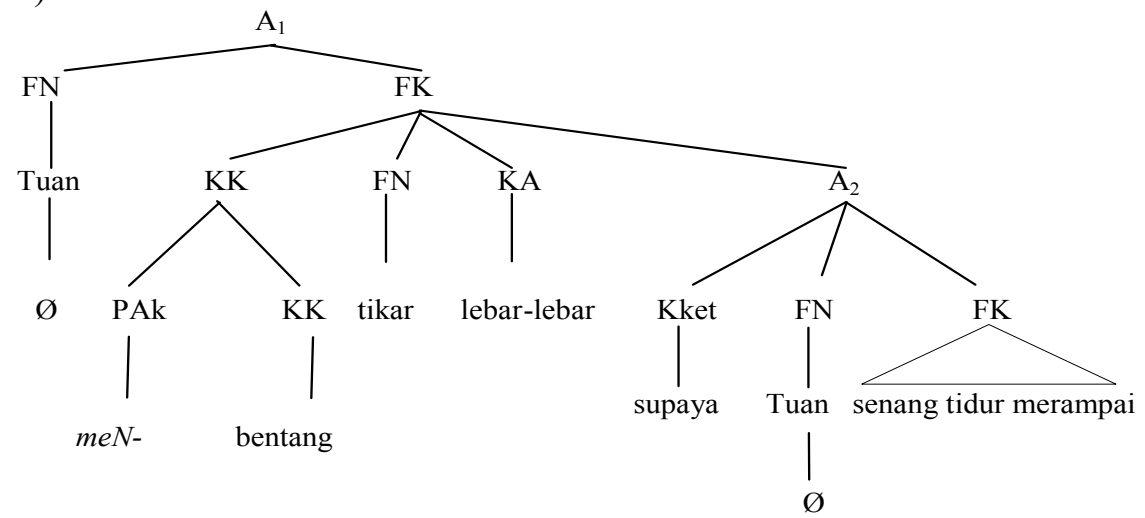

Dalam struktur permukaan, subjek $\mathrm{A}_{1}$ dan subjek $\mathrm{A}_{2}$, iaitu tuan telah digugurkan Kedua-dua ayat terhasil daripada predikat ayat sahaja yang terdiri daripada frasa kerja dengan unsur keterangan.

Dalam binaan $\mathrm{A}_{2}$, penanda kata kerja aktif $m e N$ - pada kata kerja bentang mengalami peleburan seperti subjek ayat dan kata hubung. Dalam struktur permukaan, imbuhan awalan meN- dalam kata kerja membentang digugurkan dan hanya wujud kata dasar bentang sahaja. Frasa yang terhasil pada struktur permukaan ialah bentang tikar lebar-lebar. 
Berdasarkan analisis yang dilakukan, ayat ini merupakan ayat majmuk keterangan harapan. Ayat ini menunjukkan bahawa hanya predikat ayat sahaja yang dikekalkan, manakala subjek tidak dipentingkan kerana telah digugurkan.

\section{Ayat Majmuk Keterangan Waktu}

Keterangan waktu ialah unsur yang menerangkan masa sesuatu perbuatan atau kejadian. Kata hubung keterangan waktu adalah seperti sejak, semenjak, setelah, sementara, tatkala dan ketika. Antara contoh pantun yang menggunakan kata hubung keterangan waktu sewaktu ialah:

\section{Hujan turun renyai-renyai Berteduh di bawah perahu \\ Panggil abang di dalam serunai \\ Panggil mulut orangkan tahu}

Dalam pantun 380 ayat majmuk keterangan ialah hujan turun renyairenyai berteduh di bawah perahu yang binaan struktur dalamannya adalah seperti ayat yang berikut:

S-D: Saya berteduh di bawah perahu sewaktu hujan turun renyai-renyai. Ayat ini terbina daripada dua ayat tunggal yang menjadi binaannya iaitu:

a) Saya berteduh di bawah perahu.

FN FK

b) Hujan turun renyai-renyai.

FN FK

Binaan $A_{1}$ dan $A_{2}$ terdiri daripada subjek frasa nama, manakala predikatnya ialah frasa kerja. Dalam struktur permukaan, subjek kata ganti nama $\mathrm{A}_{1}$ mengalami peleburan. Oleh hal yang demikian, subjek ayat boleh sahaja diletakkan dengan mana-mana kata ganti nama diri seperti saya, $a k u$, anda dan sebagainya. Binaan ayat dalam struktur dalaman ditunjukkan seperti rajah pohon di bawah: 


\section{$\underline{\text { Rajah Pohon S-D }}$}

a)

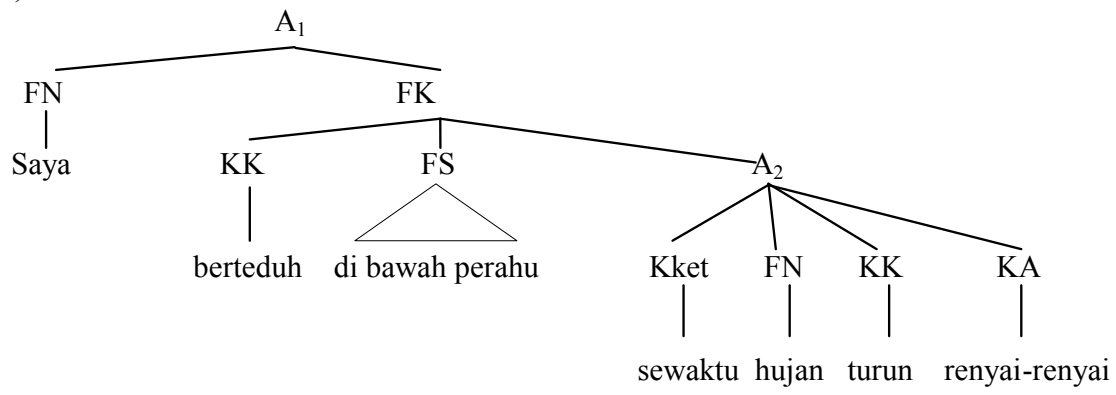

Pola $\mathrm{A}_{1}$ dibentuk berdasarkan binaan subjek kata nama dan predikat frasa kerja. Subjek $\mathrm{A}_{1}$ ialah saya, manakala predikatnya ialah berteduh di bawah perahu. Binaan frasa kerja terdiri daripada kata kerja iaitu, berteduh dan unsur keterangan di bawah perahu. $\mathrm{A}_{1}$ dan $\mathrm{A}_{2}$ dihubungkan dengan kata hubung gabungan keterangan waktu sewaktu. Dalam $\mathrm{A}_{1}$ berlaku pengguguran subjek kata ganti nama.

Binaan $\mathrm{A}_{2}$ terhasil daripada subjek kata nama, iaitu hujan dan predikat frasa kerja, iaitu turun renyai-renyai. Ayat S-D ini mengalami proses transformasi seperti yang ditunjukkan dalam rajah di bawah:

b)

\section{Rajah Pohon S-P}

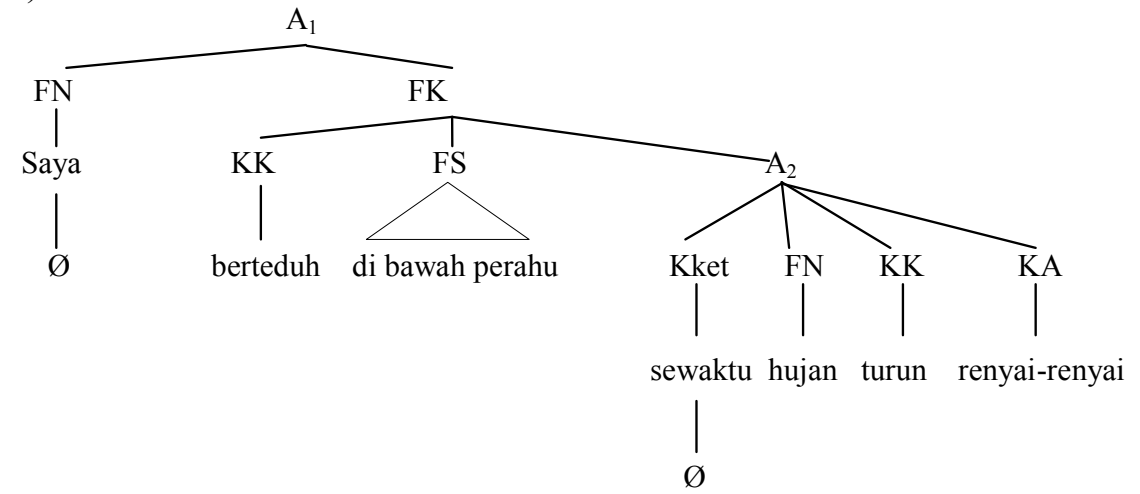

Dalam ayat ini, pengguguran kata hubung keterangan sewaktu berlaku kerana telah menjadi kelaziman kata hubung dalam pantun digugurkan. Penggunaan kata hubung sewaktu digugurkan apabila gabungan dua frasa 
kerja berteduh di bawah perahu dan turun renyai-renyai berlaku. Sekiranya frasa tersebut disusun semula dengan kehadiran subjek kata nama dalam $\mathrm{A}_{1}$ dan kata keterangan frasa ini akan terdiri daripada konstituen Sewaktu hujan turun renyai-renyai saya berteduh di bawah perahu.

Dalam ayat ini, berlaku proses penyusunan semula. Ayat sewaktu hujan turun renyai-renyai saya berteduh di bawah perahu merupakan binaan ayat songsang yang keterangan waktu mengalami penyongsangan di hadapan ayat induk.

Berdasarkan analisis yang telah dilakukan dalam pantun ini, berlaku proses pengguguran kata hubung keterangan dan subjek kata nama. Selain daripada itu, dalam ayat ini juga berlaku proses penyusunan semula melalui penyongsangan. Proses transformasi ini berlaku apabila keterangan hendak difokuskan.

\section{KESIMPULAN}

Perbincangan dan analisis terhadap pantun mendapati bahawa binaan ayat majmuk pancangan yang digunakan ialah ayat majmuk pancangan relatif, ayat majmuk pancangan komplemen dan ayat majmuk keterangan. Kesemua jenis ayat ini telah mengalami proses transformasi, iaitu pengguguran, penyusunan semula dan peluasan ayat.

Proses transformasi yang berlaku ini jelas memperlihatkan kecerdikan anggota masyarakat dalam melahirkan buah fikiran yang ringkas dan padat. Proses transformasi ini berlaku kerana yang mementingkan nilai estetika dalam binaannya, iaitu dari aspek jumlah suku kata. Namun demikian, dalam karya-karya kreatif, kelonggaran diberikan dari segi hukum-hukum bahasa demi mempertahankan keindahan karya.

\section{Singkatan}

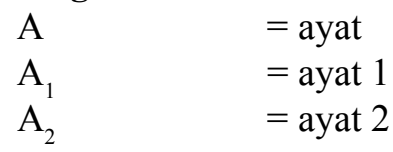




\begin{tabular}{|c|c|}
\hline $\mathrm{KN}$ & $=$ kata nama \\
\hline KK & $=$ kata kerja \\
\hline KA & $=$ kata adjektif \\
\hline $\mathrm{FN}$ & $=$ frasa nama \\
\hline FK & $=$ frasa kerja \\
\hline FS & $=$ frasa sendi nama \\
\hline$\overline{\mathrm{A}}$ & $=$ ayat komplemen \\
\hline Kkomp & $=$ kata komplemen \\
\hline KET & $=$ keterangan \\
\hline Kket & $=$ kata keterangan \\
\hline PAk & $=$ penanda aktif \\
\hline $\mathrm{KGN}$ & $=$ kata ganti nama \\
\hline $\mathrm{KGN}_{1}$ & $=$ kata ganti nama pertama \\
\hline $\mathrm{KGN}_{2}$ & $=$ kata ganti nama kedua \\
\hline S-D & $=$ struktur dalaman \\
\hline S-P & $=$ struktur permukaan \\
\hline$i$ & $=$ identikel \\
\hline$\varnothing$ & $=$ digugurkan \\
\hline
\end{tabular}

\section{NOTA}

\footnotetext{
${ }^{1}$ Angka-angka yang tertera di sebelah kiri pantun ini merupakan nombor bilangan pantun yang terdapat dalam buku Pantun Melayu karya R.J. Wilkinson dan R.O. Winstedt.
}

\section{RUJUKAN}

Ab. Razak Ab. Karim. (1996). Pantun Melayu lama: Analisis penggunaan kata dan ayat. Jurnal Dewan Bahasa, 40 (4), pp. 306-320.

Ab. Razak Ab. Karim. (2011). Pantun Melayu lama: Sumber terbaik pengajaran sintaksis. Kembali kepada akar menjana paradigma baharu (hlm. 187-205). Singapura: Oxford Graphic Printers Pte Ltd.

Asmah Hj. Omar. (2009). Nahu Melayu mutakhir. Kuala Lumpur: Dewan Bahasa dan Pustaka.

Chomsky, N. (1957). Syntactic structures. The Hague: Mouton.

Chomsky, N. (1965). Aspects of the Theory of Syntax. Massachusetts: MIT Press.

Hashim Musa. (1989). Sintaksis Bahasa Melayu suatu huraian berdasarkan rumus struktur frasa. Kuala Lumpur: Express Printers Sdn. Bhd.

Nik Safiah Karim. (1978). Bahasa Malaysia syntax: Some aspects of its standardization. Kuala Lumpur: Dewan Bahasa dan Pustaka. 
Nik Safiah Karim. (1979). Ayat majmuk dalam Bahasa Melayu. Dewan Bahasa, 23(1), pp. 9-17.

Nik Safiah Karim (Ed.). 1980. Bahasa Melayu: Teori dan aplikasinya. Kuala Lumpur: Sarjana Enterprise.

Nik Safiah Karim. (1988). Linguistik transformasi generatif: Suatu penerapan pada bahasa Melayu. Kuala Lumpur: Dewan Bahasa dan Pustaka.

Nik Safiah Karim. (1996). Pantun Melayu: Satu garapan struktur ayat. Dlm. Wan Ab. Kadir Wan Yusoff (Ed.). Pantun dan manifestasi minda masyarakat (hlm. 15-25). Kuala Lumpur:Universiti Malaya, Akademi Pengajian Melayu.

Nik Safiah Karim. (1997). Keindahan pantun dari sudut sintaksis bahasa Melayu. Seminar Kebangsaan Tradisi Lisan Melayu, Jabatan Kesusasteraan Melayu, Akademi Pengajian Melayu, Universiti Malaya.

Nik Safiah Karim. (2006)). Keindahan bahasa Melayu dalam pantun. Dlm. Rogayah A. Hamid \& Jumaah Ilias (Ed.). Pandangan semesta Melayu pantun (hlm.136-163). Kuala Lumpur: Dewan Bahasa dan Pustaka.

Nik Safiah Karim et al. (2010). Tatabahasa Dewan. Kuala Lumpur: Dewan Bahasa dan Pustaka.

Wilkinson, R.J. \& Winstedt, R.O. (1961). Pantun Melayu. Singapore: Malay Publishing House Ltd.

Winstedt, R.O. (1969). A history of classical Malay literature. Kuala Lumpur: Oxford University Press.

Zainal Abidin Ahmad. (1965). Ilmu mengarang Melayu. Kuala Lumpur: Dewan Bahasa dan Pustaka.

Zainal Abidin Ahmad. (2000). Pelita bahasa Melayu penggal I-III. Kuala Lumpur: Dewan Bahasa dan Pustaka. 
